\title{
PEMBINAAN KEAGAMAAN ANAK DI LEMBAGA PEMASYARAKATAN DI KABUPATEN BULUKUMBA DAN BANTAENG
}

\author{
CHILDREN'S RELIGIOUS COACHING IN A \\ CORRECTIONAL FACILITY IN BULUKUMBA AND \\ BANTAENG REGENCIES
}

\author{
Abdul Rahman Arsyad \\ Balai Penelitian dan Pengembangan Agama Makassar \\ Kantor Jl. A. P. Petta Rani No. 72 Makassar \\ E-mail: arsyadrahman056@gmail.com
}

Naskah diterima 7 Januari 2017, direvisi 23 Februari 2017, disetujui 20 Maret 2017

\begin{abstract}
The study was conducted in the Correctional Facility of Bulukumba and the Detention House of Bantaeng using qualitative method. The study issue includes how to foster children's religious in correctional institutions with the aim at revealing and describing the process, behavioral impacts, support and barrier to religious coaching for prisoners of the Correctional Facility (WBP). The result of the study shows that religious coaching is carried out in an integrated manner implemented in a mosque and skill room by using an assistance method (cadreisation) focusing on figh (salat) and reading the Qur'an (BTQ) separately between male and female WBP. The role of religious organization (Wahdah) and prisoners of the Correctional Facility (WBP) helps the Correctional Facility/ Detention House authorities contribute to the religious coaching. Although on the other hand, the optimization of the religious coaching has not worked maximally because the synergy between the Minister of Justice and Human Rights and the Ministry of Religious Affairs (counselor of religion) was vacant since 2008 to 2009. The Correctional Facility/Detention managers have limitation in implementing the religious coaching: a) Ratio between the coach and WBP is not balanced; $b$ ) Coaching is naturally applied; c) Knowledge of the Correctional Facility/Detention managers on religious and religious knowledge is actualized by experience; d) lack of media support and coaching facilities (religious and spatial books) and e) Schedule of coaching activities has not been consistent.
\end{abstract}

Keywords: Religious Coaching, Children, Correctional Facility and Detention House
Abstrak

Penelitian dilaksanakan di Lapas Bulukumba dan Rutan Bantaeng dengan menggunakan metode kualitatif. Masalah penelitian memuat tentang bagaimana pembinaan keagamaan anak di lembaga pemasyarakatan dengan tujuan mengungkap dan menggambarkan proses, dampak perilaku, pendukung dan penghambat terhadap pembinaan keagamaan bagi warga binaan pemasyarakatan (WBP). Hasil penelitian menunjukkan bahwa pembinaan keagamaan dilaksanakan secara integrasi yang dilaksanakan di masjid dan ruang keterampilan dengan menggunakan metode asistensi (kaderisasi) yang fokus pada fiqh (salat) dan baca tulis Qur'an (BTQ) secara terpisah antara WBP pria dan wanita. Peran organisasi keagamaan (Wahdah) dan warga binaan pemasyarakatan (WBP) sangat membantu pihak lapas/rutan dalam memberikan kontribusi pembinaan keagamaan. Meskipun di sisi lain, optimalisasi pembinaan keagamaan belum berjalan secara maksimal, karena sinergisitas antara Menkumham dan Kementerian Agama (penyuluh Agama) terjadi kevakuman sejak tahun 2008 s/d 2009. Pihak pengelola (pembina) lapas dan rutan memiliki keterbatasan dalam mengimplementasikan pembinaan keagamaan, diantaranya: a) Rasio antara pembina dan WBP tidak seimbang; b) Pembinaan diaplikasikan secara alami; c) Pengetahuan pengelola (pembina) lapas/rutan tentang pengetahuan agama dan keagamaan diaktualisasikan berdasarkan pengalaman; d) Minimnya dukungan media dan fasilitas (buku-buku agama dan ruang) pembinaan; dan e) Jadwal kegiatan pembinaan belum konsisten.

Kata Kunci: Pembinaan Keagamaan, Anak, LAPAS, dan RUTAN 


\section{PENDAHULUAN}

Pendidikan dinilai memiliki peran penting dalam upaya menanamkan rasa keagamaan pada seseorang anak. Sehingga peran pendidikan di keluarga, lingkungan, pendidikan kelembagaan, pendidikan di masyarakat, agama dan masalah sosial sangat berperan dalam membentuk sikap keagamaan anak/remaja. ${ }^{1}$ Kriminalitas termasuk masalah sosial dan merupakan penyimpangan sosial dalam masyarakat. Pelbagai tindakan kriminal sering dijumpai secara langsung dan tidak langsung, sebagaimana dapat dilihat dalam pemberitaan baik dari media cetak atau elektronik. Kriminalitas dapat dilakukan siapa saja, kapan saja dan di mana saja, termasuk oleh mereka yang masih tergolong anak-anak.

Menurut Biro Pengendalian Operasi Mabes Polri yang dilangsir oleh BPS Kriminal tahun 2014 jumlah kejahatan yang menonjol tahun 2011-2013, yaitu: pembunuhan, penganiayaan, kesusilaan, penculikan, pencurian, narkotika, dan korupsi. Adapun jumlah kejahatan tahun 2011 (347.605), tahun 2012 (341.159), dan tahun 2013 (342.084). Terkait dengan tingkat kriminal yang terjadi di Indonesia. Menurut numbeo.com, dari indeks kejahatan pada tahun 2015 Indonesia berada pada peringkat 68 dari 147 Negara dan kejahatan yang tercermin dari tahun ke tahun. Sedangkan perhitungan BPS Indonesia, periode 2013 setiap dalam 1 menit 23 detik terjadi satu tindakan kriminal, sementara dari 100.000 orang terdapat 140 orang beresiko terkena tindakan kejahatan (crime rate) (Data registrasi POLRI: ringkasan eksekutif statistik kriminal, 2014).

Kemenkumham RI melansir dari sejumlah lembaga pemasyarakatan yang tersebar di Indonesia (tahanan/napi anak) tiga tahun terakhir (2014-2016) lewat SDP (sistem database pemasyarakatan). Adapun jumlah tahanan/napi anak dan jumlah tahanan dan napi secara keseluruhan, yaitu: (1) tahun 2014 jumlah tahanan/napi anak 5.118 orang (tahanan 1.936 orang dan napi 3.182 orang) dari 164.170 tahanan dan napi; (2) tahun 2015 jumlah tahanan/napi anak 3.590 (tahanan 869 orang dan napi 2.721 orang) dari 170.637 tahanan dan napi; dan (3) tahun 2016 jumlah tahanan/napi anak 3.127 (tahanan 838 orang dan napi 2.289 orang) dari 187.049 tahanan dan napi. (SDP smslap. ditjenpas.go.id/public/grl/current/monthly).

Secara umum pemerintah memberi pembinaan bagi para pelaku tindak kriminal (narapidana) yang dilaksanakan melalui Lembaga Pemasyarakatan. "Pembinaan itu mempunyai arti memperlakukan seseorang yang berstatus narapidana untuk dibangun agar bangkit menjadi seseorang yang baik. Atas dasar pengertian pembinaan yang demikian itu, sasaran yang perlu dibina adalah pribadi dan budi pekerti narapidana, yang didorong untuk membangkitkan rasa harga diri pada diri sendiri dan pada diri orang lain, serta mengembangkan rasa tanggung jawab untuk menyesuaikan diri dengan kehidupan yang tenteram dan sejahtera dalam masyarakat dan selanjutnya

1 Jalaluddin. 1996. Psikologi Agama. Pengaruh Pendidikan Terhadap Jiwa Keagamaan, Jakarta: PT. Raja Grafindo Persada. h. 251 
berpotensi untuk menjadi manusia yang berkepribadian dan bermoral tinggi". ${ }^{2}$

Secara khusus, narapidana anak memiliki sejumlah hak yang perlu dipenuhi pemerintah. Hak asasi anak termuat dalam Undang-Undang Dasar 1945 dan Konvensi Perserikatan Bangsa-Bangsa (PBB) tentang hak anak. Salah satu hak anak adalah memperoleh pengajaran agama sesuai yang mereka anut.Regulasi telah mengatur hal ini dalam rangka melindungi hak anak untuk memperoleh pendidikan agama dalam kehidupan mereka. Di dalam UU No 23 Tahun 2002 tentang Perlindungan Anak, Pasal 43 menyebutkan perlindungan hak anak dalam memeluk agamanya meliputi pembinaan, pembimbingan, dan pengamalan ajaran agama bagi anak.

Pembinaan narapidana/warga binaan dilakukan secara terus menerus sejak warga binaan masuk dalam lembaga pemasyarakatan. Sistem pemasyarakatan merupakan suatu proses pembinaan warga binaan sebagai makhluk Tuhan, individu dan sebagai masyarakat. Dalam pembinaan warga binaan dikembangkan keadaan jasmani, rohani serta kemasyarakatannya dan dibutuhkan pula elemen-elemen yang berkaitan untuk mendukung keberhasilan dalam pembinaan. Elemen-elemen tersebut adalah lembaga-lembaga yang berkaitan dengan pengembangan semua segi kehidupan warga binaan dan tenaga-tenaga pembina yang cukup cakap dan penuh dengan rasa pengabdian. ${ }^{3}$

${ }^{2}$ Poernomo, Bambang. 1986. Pelaksanaan Pidana Penjara dengan Sistem Pemasyarakatan. Yogyakarta: Liberty. h. 187.

${ }^{3}$ Dwidja Priyatno. 2006. Pidana Penjara di Indonesia. Bandung: Refika Aditama. h. 105-106
Setiap warga negara berhak mendapatkan pendidikan/pembinaan keagamaan, baik lewat pendidikan formal maupun pendidikan non-formal. Karena pendidikan agama merupakan konsep pendidikan bertujuan untuk membina dan mencerahkan jiwa manusia. Berdasar itu, maka masalah penelitian dapat dirumuskan sebagai berikut: 1) Bagaimana pembinaan keagamaan dan dampak perilaku warga binan pemasyarakatan anak di lembaga pemasyarakatan; 2) Bagaimana faktor pendukung dan penghambat pembinaan keagamaan di lembaga pemasyarakatan?

Penelitian ini difokuskan pada penelusuran terkait pelaksanaan pembinaan agama yang dilakukan di lingkungan lapas terhadap narapidana anak. Termasuk pula sebagai fokus penelitian adalah faktor-faktor yang menjadi pendukung dan penghambat pelaksanaan pembinaan keagamaan terhadap narapidana anak yang dilakukan dan diprogramkan dalam lapas.

\section{Kerangka Konseptual}

\section{Pembinaan Keagamaan}

Pembinaan dalam arti bahasanya adalah: menyeru, mengajak, memanggil, mengundang, mendoakan yang terkandung di dalamnya arti menyampaikan sesuatu kepada orang lain untuk mencapai tujuan tertentu. ${ }^{4}$ Pembinaan Islamiyah berarti: menyeru, mengajak dan memberikan pengertian serta bimbingan manusia untuk beriman kepada Allah SWT dan mentaati-Nya, sesuai dengan garis yang

${ }^{4} J a m a l u d d i n$ Kafie. 1993. Psikologi Dakwah. Surabaya: Indah Press. h. 29 
telah diwahyukan oleh Allah SWT dan disunnahkan Rasulullah SAW. ${ }^{5}$

Pembinaan adalah usaha, tindakan, dan kegiatan yang dilakukan secara efektif dan efisien untuk memperoleh hasil yang lebih baik. ${ }^{6}$ Sedangkan keagamaan berarti segala sesuatu yang berhubungan dengan agama. ${ }^{7}$ Jadi pembinaan keagamaan dalam penelitian ini adalah segala aktifitas keagamaan, yang meliputi pemahaman penghayatan pengamalan ajaran agama Islam bagi narapidana anak khususnya agama Islam yang dilakukan di lembaga pemasyarakatan yang bertujuan untuk membina para narapidana melalui pendekatan religius.

\section{Narapidana Anak}

Berdasarkan ketentuan umum pasal 1 angka 7 Undang Undang Nomor 12 Tahun 1995 dinyatakan bahwa yang dimaksud dengan narapidana adalah “Terpidana yang menjalani pidana hilang kemerdekaannya di lembaga pemasyarakatan". Pembinaan merupakan upaya untuk menyadarkan narapidana atau anak pidana agar menyesali perbuatannya, dan mengembalikannya menjadi warga masyarakat yang baik, taat kepada hukum, menjunjung tinggi nilainilai norma, sosial dan keagamaan, sehingga tercapai kehidupan masyarakat yang aman tertib dan damai. Narapidana anak menurut KUHP pasal 45 adalah: anak yang belum dewasa dan mencapai genap umur 21 tahun, belum menikah dan anak tersebut melakukansesuatuyangdianggapmelanggar

${ }^{5}$ Sahilun A. Nasir. 1999. Ilmu Dakwah. Jember: STAIN Press. h. 4

${ }^{6}$ Alwi, Hasan. 2002. Kamus Bahasa Indonesia. Jakarta: Balai Pustaka. h. 152

${ }^{7}$ Ibid. h. 12 peraturan hukum yang berlaku baik hukum perundang-undangan atau hukum yang lain dan sekarang berada dalam rumah tahanan atau lembaga pemasyarakatan.

\section{Pola Pembinaan Narapidana dalam Sistem Pemasyarakatan}

Sistem Pemasyarakatan di negara kita dalam kenyataannya belum dapat dikatakan sebagai suatu sistem pemasyarakatan yang sesungguhnya. Gunakaya berpendapat apabila kita membahas tentang sistem pemasyarakatan yang sesungguhnya harus memiliki beberapa unsur, yaitu: 1) harus adanya sarana peraturan perundangundangan dan praturan pelaksanaannya, yang merupakan landasan struktural yang menunjang atau melaksanakan dasar bagi ketentuan-ketentuan operasional suatu konsepsi, dalam hal ini konsepsi pemasyarakatan; 2) harus tersedia sarana personil yang mencukupi dan memadai bagi kebutuhan pelaksanaan tugas pembinaan narapidana; 3) sarana administrasi keuangan, sebagai sarana materiil untuk keperluan operasional; dan 4) sarana fisik yang sesuai dengan kebutuhan bagi pelaksanaan pembinaan narapidana dalam proses pemasyarakatan. ${ }^{8}$

Dalam rangka usaha ke arah diperolehnyakeseragaman dalam tindakan pembinaan bagi narapidana maka berdasarkan hasilhasil rapat kerja Direktorat Jenderal Bina Tuna Warga pada tahun 1976, di beberapa wilayah Pemasyarakatan telah disusun pola-pola pembinaan narapidana dalam LP sebagai berikut: a) Pola Penerimaan/ Pendaftaran Warga Baru (Perihal Admis

\footnotetext{
${ }^{8}$ A. Widiada Gunakaya. 1988. Sejarah dan Konsepsi Pemasyarakatan. Bandung: Armico.

h. 130-131
} 
dan Orientasi, dan Perihal Klasifikasi/ Diversifikasi), b) Pola Perawatan Narapidana (Perihal Pakaian, Makanan, Kesehatan dan Dinas Medis, dan Pemberitahuan Sakit dan Kematian Narapidana), c) Pola Tata Tertib Disiplin Narapidana (Perihal Tata Tertib, dan Prosedur Mengajukan Keluhan/ Pengadaan Narapidana), d) Pola Bimbingan/ pendidikan Agama Bagi Narapidana (Perihal Umum, dan Program Keagamaan), e) Pola Pendidikan dan Rekreasi Bagi Narapidana (Perihal Pendidikan, Rekreasi, Pendidikan Kepramukaan, Perpustakaan), f) Pola Pekerjaan Narapidana (Perihal Pekerjaan Narapidana, Jenis Pekerjaan Narapidana, Syarat Pemberian Pekerjaan, Hasil-hasil Pekerjaan, dan Pemberian Imbalan Jasa), g) Pola Pelaksanaan Mekanisme Kerja Dewan Pembina Pemasyarakatan Dalam Instalansi Pelaksanaan (Status dan Susunan Dewan Pembina Pemasyarakatan, Sidang-sidang Dewan Pembina Pemasyarakatan), h) Pola Tentang Hak-hak Narapidana dan lainlain (Perihal Hubungan Dengan Pihak Lain, Pelaksanaan Pemberian Remisi, Perihal Pelaksanaan Pemberian Cuti dan sebagainya, Penyelenggaraan Integrasi, dan Pelaksanaan Lepas Bersyarat), i) Pola Pengangkutan, Pemindahan dan Peminjaman Narapidana (Perihal Pengangkutan Narapidana, Pemindahan Narapidana, Peminjaman Narapidana), j) Pola Tentang Keamanan, k) Pola Pemeliharaan Sarana Fisik LP. ${ }^{9}$

\section{Pemasyarakatan}

Narapidana adalah seorang yang dipidana berdasarkan putusan pengadilan

${ }^{9}$ Dipraja, R. Achmad S. Soema dan Romli Atmasasmita, 1979. Sistem Pemasyarakatan di Indonesia. Bandung: Percetakan Ekonomi. h. 64-65 yang telah memperoleh kekuatan hukum tetap. ${ }^{10}$ Narapidana adalah terpidana yang menjalani pidana hilang kemerdekaan di lapas. ${ }^{11}$ Narapidana merupakan terpidana yang sedang menjalani pidana hilang kemerdekaan.a. Anak Didik Pemasyarakatan adalah: (1) Anak Pidana yaitu anak yang berdasarkan putusan pengadilan menjalani pidana di lapas anak paling lama sampai berumur 18 (delapan belas) tahun; (2) Anak negara yaitu anak yang berdasarkan putusan pengadilan diserahkan pada negara untuk dididik dan ditempatkan di lapas anak paling lama sampai berumur 18 (delapan belas) tahun; (3) Anak sipil yaitu anak yang atas permintaan orang tua atau walinya memperoleh penetapan pengadilan untuk dididik di lapas anak paling lama sampai berumur 18 (delapan belas) tahun; b. Lembaga pemasyarakatan; sebagai instansi terakhir di dalam sistem peradilan pidana dan pelaksanaan putusan pengadilan (hukum) di dalam kenyataannya tidak mempersoalkan, apakah seseorang terbukti bersalah atau tidak. ${ }^{12}$ Lembaga pemasyarakatan (lapas) adalah merupakan tempat dilakukan kegiatan pembinaan mental, dan di ruang mana saja dijadikan sebagai tempat kegiatan, waktu-waktu apa saja, serta siapa yang terlibat dalam kegiatan tersebut.

Pendidikan atau bimbingan merupakan saranayangmendukung keberhasilannegara menjadikan narapidana menjadi anggota

\footnotetext{
${ }^{10}$ Bambang Waluyo. 2000. Pidana dan Pemidanaan. Jakarta: Sinar Grafika. h. 36

${ }^{11}$ Ibid. h. 78

${ }^{12}$ Panjaitan, Petrus Irwan dan Simonangkis Pandapotan. 1995. Lembaga Pemasyarakatan dalam Perspektif Sistem Peradilan Pidana. Jakarta: Pustaka Sinar Harapan. h. 37
} 
masyarakat. Lembaga pemasyarakatan berperan dalam pembinaan narapidana anak yang memperlakukan narapidana anak agar menjadi lebih baik, yang perlu dibina adalah pribadi narapidana, membangkitkan rasa harga diri dengan kehidupan yang tentram dan sejahtera dalam masyarakat, sehingga potensial menjadi manusia yang berkepribadian dan bermoral tinggi. ${ }^{13}$

Pendidikan narapidana di lapas mempunyai arti memperlakukan seseorang yang berstatus narapidana untuk dibangun agar bangkit menjadi seseorangyang berbudi pekerti yang baik. Dan salah satu tujuannya yaitu berusaha ke arah memasyarakatkan kembali seseorang yang pernah mengalami konflik sosial, menjadi seseorang yang benar-benar sesuai dengan jati dirinya.

Sehingga dapat dipahami bahwa tujuan akhir dari sistem pemasyarakatan adalah memulihkan kesatuan hubungan sosial (reintegrasi sosial) Warga Binaan Pemasyarakatan dengan/ke dalam masyarakat. Khususnya masyarakat di tempat tinggal asal mereka melalui suatu proses (proses pemasyarakatan/pembinaan) yang melibatkan unsur-unsur atau elemen-elemen, petugas pemasyarakatan, narapidana dan masyarakat.

\section{Perlakuan WBP Anak}

Anak menurut Undang-Undang Nomor 23 tahun 2002 tentang Perlindungan Anak adalah: Seseorang yang belum berusia 18 (delapan belas) tahun, termasuk anak yang masih dalam kandungan. Adapun proses pembinaan anak dapat dimulai dari lingkup

13 Gultom Muidin. 2008. Perbandingan Hukum Terhadap Anak dalam Sistim Peradilan Pidana Anak di Indonesia, Jakarta: Refika Aditama. h. 126 terkecil yakni dalam kehidupan berkeluarga. Pada lingkup inilah yang paling memberikan pengaruh besar kepada baik buruknya anak. Pada dasarnya kesejahteraan anak tidak sama, tergantung dari tingkat kesejahteraan orang tuanya.

Penempatan secara khusus dalam lapas anak berarti pembinaan narapidana anak dilakukan dalam sistem pemasyarakatan. Menurut ketentuan Pasal 60 UndangUndang No. 3 Tahun 1997 tentang Pengadilan Anak, bahwa Anak didik pemasyarakatan ditempatkan di lapas yang terpisah dari narapidana dewasa. Anak yang ditempatkan di lapas anak, berhak memperoleh pendidikan dan latihan baik formal maupun informal sesuai bakat dan kemampuan, serta memperoleh hak lain. Guna melaksanakan pemasyarakatan dan sistem pemasyarakatan tersebut dilakukan oleh suatu lembaga, yaitu lapas yang merupakan tempat untuk melaksanakan pembinaan narapidana dan anak didik pemasyarakatan (vide Pasal 1 angka 3 UUP No. 12 Tahun 1995).

"Melalui pelaksanaan pembinaan dengan sistem pemasyarakatan maka Anak Didik Pemasyarakatan diharapkan menyadari kesalahannya, memperbaiki diri dan tidak mengulangi tindak pidana lagi. Pada akhirnya diharapkan dapat diterima kembali oleh lingkungan masyarakat, dan dapat ikut aktif berperan dalam pembangunan, dapat hidup secara wajar sebagai warga yang baik dan bertanggung jawab". ${ }^{14}$

Peraturan Pemerintah Republik Indonesia Nomor 32 Tahun 1999 tentang Syarat dan Tata Cara Pelaksanaan Hak Warga Binaan Pemasyarakatan khususnya

${ }^{14}$ Darwan Print. 2003. Hukum Anak Indonesia. Bandung: PT. Citra Aditya Bakti. h. 58 
pasal yang mengatur tentang pendidikan dan pengajaran yaitu Pasal 9 sampai Pasal 13

Selanjutnya setiap napi berhak mengikuti pembinaan melalui program Asimilasi, yang meliputi: 1) Asimilasi ke dalam yaitu: a) Pendidikan agama, b) Olah raga, dan c) Keterampilan; 2) Asimilasi keluar, yaitu: pembinaan ini dititikberatkan pada atau di luar lembaga pemasyarakatan dengan pengawalan dari petugas pemasyarakatan. Wujud pembinaan ini adalah: a) Perkebunan di sekitar lembaga pemasyarakatan, b) Bekerja membersihkan halaman kantor lembaga pemasyarakatan, dan c) Pemberian izin untuk alasan penting.

\section{Pendidikan Keagamaan Anak}

Berdasarkan ketentuan Pasal 6 Undang - Undang Nomor 12 Tahun 1995, dinyatakan bahwa: Pembinaan Warga Binaan Pemasyarakatan dilakukan di lapas dan pembimbingan warga binaan pemasyarakatan dilakukan oleh Lapas. Sedangkan pembinaan di lapas dilakukan terhadap narapidana dan anak didik pemasyarakatan.

Sistem pembinaan pemasyarakatan dilaksanakan berdasarkan asas: a) Pengayoman, b) Persamaan perlakuan dan pelayanan, c) Pendidikan, d) Pembimbingan, e) Penghormatan harkat dan martabat manusia, f) Kehilangan kemerdekaan merupakan satu-satunya penderitaan, g) Terjaminnya hak untuk tetap berhubungan dengan keluarga dan orang-orang tertentu.

Dalam hal pemidanaan anak tidak dapat diperlakukan sama dengan orang dewasa karena anak yang mendapatkan sanksi pidana sebenarnya adalah korban dari lingkungan sekitarnya. Jadi, tujuan dan dasar pemikiran dari pembinaan anak tidak dapat dilepaskan dari tujuan utama untuk mewujudkan kesejahteraan anak yang pada dasarnya merupakan bagian integral dari kesejahteraan sosial, dalam arti bahwa kesejahteraan atau kepentingan anak berada dibawah kepentingan masyarakat. Akan tetapi harus dilihat bahwa mendahulukan kesejahteraan dan kepentingan anak itu pada hakikatnya merupakan bagian dari usaha mewujudkan kesejahteraan sosial. ${ }^{15}$

Perbedaan perlakukan dan ancaman yang diatur dalam Undang-undang Sistem Peradilan Pidana Anak dimaksudkan untuk lebih memberikan perlindungan dan pengayoman terhadap anak dalam menyongsong masa depannya yang masih penjang. Selain itu, pembedaan tersebut dimaksudkan untuk memberikan kesempatan kepada anak agar setelah melalui pembinaan akan diperoleh jati dirinya untuk menjadi manusia yang lebih baik, yang berguna bagi diri, keluarga, masyarakat, bangsa dan negara. ${ }^{16}$

Lalu mengenai perlindungan hukumnya, hal ini dapat diwujudkan antara lain dengan dilakukannya beberapa usaha sebagai berikut: pembinaan, pendampingan, pengawasan, penjaminan pendidikan kontruktif, integratif, kreatif, positif, dan usaha ini tidak boleh mengabaikan aspekaspek mental, sosial, dan fisik dari seorang narapidana anak. ${ }^{17}$

15 Sutatiek Sri. 2013. Rekontruksi Sistem Sanksi dalam Hukum Pidana Anak Indonesia. Yoyakarta: Aswojo Pressindo. h. 25

16 Wagiati Soetedjo dan Melani. 2013. Hukum Pidana Anak, Bandung: Refika Aditama. h. 27

${ }^{17}$ Ibid. h. 94 


\section{METODELOGI PENELITIAN}

Penelitian ini merupakan penelitian kualitatif bermaksud untuk memahami fenomena tentang apa yang dialami oleh subjek..$^{18}$ Teknik pengumpulan data yang digunakan dalam penelitian adalah wawancara, observasi, telaah dokumen. Wawancara dilakukan untuk menghimpun data yang terkait dengan komponen pembinaan lewat Kepala LAPAS, Kepala Tata Usaha, Kepala Seksi Pembina Keagamaan, Guru atau Sipir, Narapidana Anak, Observasi dilakukan untuk menghimpun data terkait dengan pelaksanaan pembinaan keagamaan anak di lingkungan LAPAS, sedangkan telaah dokumen dilakukan untuk menghimpun data tertulis terkait dengan jenis pembinaan keagamaan. Data yang sifatnya kualitatif diperoleh dari hasil wawancara dan studi dokumen dianalisis dengan teknik analisis kualitatif model interaktif yang secara simultan terdiri atas tahapan, diantaranya: pengumpulan data, pengklasifikasiaan data, penyajian data, dan penarikan simpulan/verifikasi. ${ }^{19}$ Penelitian Pembinaan Keagamaan Anak di Lembaga Pemasyarakatan dilaksanakan di Kab. Bulukumba dan Bantaeng propinsi Sulawesi Selatan selama lima belas hari.

\section{HASIL DAN PEMBAHASAN}

\section{Setting Penelitian}

Kabupaten Bulukumba dan Kabupaten Bantaeng merupakan wilayah bertetangga, masing-masing memiliki wadah atau lembaga yang dapat membina para pelanggar

18 Lexy J. Moleong. 2011. Metodologi Penelitian Kualitatif. Bandung: PT. Rosdakarya. h. 6

${ }^{19}$ Ibid. h. 280 hukum dengan berbagai kasus serta memiliki kategori dan kapasitas yang berbeda, diantaranya: Sarana dan prasasarana, SDM para pembina serta kondisi warga binaan pemasyarakatan (WBP) secara kuantitas.

Secara kuantitas warga binaan pemasyarakatan terbilang lebih banyak di lapas dibanding rutan, baik WBP dewasa dan anak (priadan wanita), sehingga pelaksanaan kegiatan pembinaan nampak ada perbedaan dalam hal waktu dan kesempatan para pembina. Lokasi penelitian terbilang sangat strategis, karena berdekatan dengan POLRES dan KORAMIL sehingga memudahkan pihak MENKUMHAM dalam koordinasi apabila terjadi sesuatu.

Masing-masing lapas dan rutan memiliki pembina dengan berlatar belakang keilmuan serta status yang berbeda pada aspek keagamaan dan keterampilan. Sedangkan yang terlibat langsung dalam pembinaan yaitu: petugas lapas/rutan, organisasi dan WBP. Adapun yang bertanggung jawab langsung dalam pembinaan di lapas dan rutan Abd. Rahman. S.Sos (Kasubsi Bimbingan Pemasyarakatan), Mansyur. S.Sos (Kasubsi Pelayanan Tahanan).

Secara kuantitas jumlah WBP yang sementara mengikuti pembinaan di Lembaga Pemasyarakatan (lapas) Kabupaten Bulukumba relatif besar dibanding WBP yang berada di Rumah Tahanan (rutan) Kabupaten Bantaeng. Adapun jumlah warga binaan pemasyarakatan lapas Bulukumba adalah 315 (pria 296 dan wanita 19) dengan warga binaan pemasyarakatan anak 3 orang dengan kasus yang berbeda; sedangkan jumlah WBP rutan Bantaeng 115 (pria 113 dan wanita 2) dengan warga binaan pemasyarakatan anak 1 orang. 
Terkait dengan nomenklatur lapas terlihat adanya perbedaan dengan rutan, terutama pada aspek kuantitas, dalam melaksanakan kegiatan pembinaan keagamaan diantaranya: 1) Bimpas Lapas Bulukumba; 3 pegawai lapas bertanggung jawab dan dibantu 2 orang WBP; Pelayanan Rutan Bantaeng, 2 pegawai rutan bertanggung jawab dan dibantu 1 orang WBP. Karena terbatasnya tenaga pengelola (pembina), sehingga pihak lapas/ rutan memberdayakan WBP yang memiliki kemampuan/kompetensi pada bidang keagamaan.

\section{Pembinaan Keagamaan Lapas dan Rutan}

\section{Pembinaan Keagamaan}

Menurut Kasubsi Bimpas (Abd. Rahman, S.Sos). Program pembinaan keagamaan yang diterapkan di lembaga pemasyarakatan dan rumah tahanan hanya terfokus pada figh dan BTQ, sedangkan untuk pengkajian atau siraman rohani terkadang dilakukan diselasela kegiatan pengajian, jumatan serta di saat memperingati hari besar Islam. Hal tersebut merupakan konsep utama yang dijadikan sebagai acuan dalam merubah pola pikir dan membentuk prilaku napi/tahanan menjadi lebih baik lagi. Pelaksanaan pembinaan diaplikasikan secara integrasi dengan cara terpisah antara napi/tahanan perempuan dan laki-laki. Hal tersebut dilakukan untuk mengefektifkan dan mengefesiensikan para pembina dalam melangsungkan suatu kegiatan keagamaan.

Sebelum melangsungkan kegiatan, terlebih dahulu WBP diwajibkan membersihkan semua ruang dan lorong (lingkungan) lapas/rutan. Selain aturan lapas/rutan, juga merupakan salah satu bentuk pembinaan keagamaan, agar terbiasa menjaga dan mengetahui tujuan, fungsi dan manfaat pentingnya menjaga kebersihan. Hal ini merupakan kegiatan rutin bagi WBP, dimana masing-masing blok memiliki kordinator untuk bertanggungjawab agar lingkungan lapas/rutan selalu kelihatan bersih. Kegiatan ini, adalah salah satu kriteria yang dijadikan sebagai aturan/ kebijakan yang dikeluarkan pihak lapas/ rutan, untuk melihat dan menilai kondite atau kondisi bagi WBP terkhusus masalah kedisiplinan dalam menjaga kebersihan setiap hari.

Implementasi pembinaan keagamaan yang diterapkan rutan dan lapas terlihat ada perbedaan dalam hal jadwal, misalnya: Rutan Bantaeng (rutin), sedangkan Lapas Bulukumba (dua kali seminggu). Adapun waktu kegiatan berlangsung sejak pukul 09.00-10.30 pagi dengan jenis kegiatan pengajian (tadarrus) yang dilaksanakan di masjid. Efektif dan efesisensinya suatu kegiatan, maka pola yang diterapkan oleh pembina dan asisten pembina adalah secara berkelompok. Strategi ini, selain memudahkan pembina dalam mengevaluasi atau mengetahui sejauh mana perkembanganWBP dalam memahami BTQ.

Polarisasi yang dikembangkan lapas Bulukumba dan rutan Bantaeng adalah pengkaderan. Pola pengkaderan diterapkan, karena adanya keterbatasan yang dimiliki, misalnya: minimnya tenaga (pengelola) pembina dan sumber daya manusia (SDM). Selain itu, bagi WBP yang mememiliki pengetahuan atau kemampuan di bidang tersebut dapat berkontribusi atau membantu pembina dalam melangsungkan aktivitas sehari-hari yang terkait dengan kegiatan BTQ. 
Menurut Mansyur. S.Sos (Kasubsi Pelayanan) dan H. Saharuddin (WBP) rutan Bantaeng, mengapa pembinaan keagamaan dilaksanakan secara rutin. Karena ini momentum yang tepat dalam memberikan pencerahan dan pengenalan bagi WBP agar dapat membentuk mentalitas dan moral serta yang tak kalah pentingnya adalah setelah bebas, mereka dapat mengabdikan dirinya dan bisa kembali menyatu di tengahtengah masyarakat khusunya pada keluarga.

Pembinaan salat yang dimaksud di sini adalah semua usaha yang ditujukan untuk memperbaiki dan meningkatkan akhlak (budi pekerti) warga binaan pemasyarakatan serta memberi bekal kepada mereka tentang ajaran-ajaran Islam sebagai pengendali sikap dan tingkah laku warga binaan baik selama di dalam maupun setelah keluar dari lembaga pemasyarakatan, karena salat merupakan tolok ukur budi pekerti warga binaan. Pembinaan salat di sini terdiri dari dua kegiatan, yaitu: 1) kegiatan utama yang meliputi pembinaan salat, 2) kegiatan pendukung meliputi, pengajian/siraman rohani, pengajaran BTQ, dan peringatan Hari Besar Islam.

Ada beberapa jenis kegiatan pembinaan keagamaan yang dikembangkan, diantaranya:

a) Baca Tulis Qur'an (BTQ), Kegiatan BTQ, merupakan program dalam pembinaan keagamaan yang harus diikuti oleh semua warga binaan, karena ini merupakan aturan/kebijakan pihak lapas/rutan, sehingga BTQ diwajibkan bagi semua WBP untuk ikut secara rutin. Dengan alasan, agar dapat cepat mengenal huruf hijaiyyah dan membaca dengan baik (tajwid).
Pembelajaran dasar (pengenalan huruf) memerlukan waktu yang relatif tidak singkat, sehingga dituntut kesabaran bagi para pembina (pengajar) dalam memberikan materi. Karena tidak semua WBP memiliki kemampuan yang sama begitupun dengan para pembina dalam penguasaan metode pembelajaran.

Pembelajaran dilakukan secara integrasi, karena adanya keterbatasan yang dimiliki pihak lapas/rutan, terutama pada aspek tenaga (pembina) dan SDM. Sehingga pembinaan kegamaan belum berjalan secara optimal, tetapi hak tersebut, tidak mengurangi semangat dalam melaksanakan kegiatan secara rutin.

Menurut WBP Lapas Bulukumba (Anto dan Haris), dengan adanya program BTQ yang diterapkan di lapas, ini merupakan salah satu aspek yang dapat membantu bagi warga binaan pemasyarakatan dalam pengenalan lebih fokus terhadap kitab suci Islam, yaitu: Al-Qur'an. Dampak dari program tersebut, terlihat sangat direspon warga binaan, misalnya: masing-masing WBP memiliki Iqra dan Qur'an, serius dalam mengikuti pembelajaran, dan saling membantu sesama warga binaan, serta kepedulian yang tinggi dalam pengadaan iqra dan Qur'an (inisiatif) melalui iuran.

b) Fiqh, Maka pembinaan salat bagi warga binaan pemasyarakatan bertujuan untuk memberi bekal agar mereka hidup sesuai dengan ajaran Islam dan mau menjalankan perintah Allah serta menjauhi larangan-Nya untuk memperoleh ketenagan, ketentraman dan kebahagiaan jiwa sehingga akan menghindarkan dari perbuatan keji dan mungkar. 
Arah dari pembinaan salat terhadap warga binaan pemasyarakatan bukan mengajarkan salat secara ritual akan tetapi lebih kepada mengajarkan salat secara aktual, yaitu: bagaimana sebenarnya hakikat dan fungsi salat dalam kehidupan sehari-hari. Karena tujuan pembinaan salat yang sesungguhnya adalah warga binaan pemasyarakatan lebih mendekatkan diri kepada Allah SWT sehingga akan mengendalikan sikap dan perbuatan mereka selama menjalani hidup.

Kegiatan ini, tidak hanya sebatas teori atau pemahaman yang diberikan oleh pembina, tetapi bagaimana warga binaan pemasyarakat dapat mengaplikasikan sehari-hari. Adapun yang diperkuat pada pembinaan ini adalah: Memperkenalkan jenis-jenis salat (wajib dan sunnah), tata cara berudhu dan salat, bacaan salat dan do'a, serta pengkaderan Imam.

Pengenalan salat tidak hanya sebatas untuk diketahui, tetapi yang terpenting bagaimana bisa mengaplikasikan. Pelaksanaan salat sunnah Duha, sebagian besar warga binaan pemasyarakatan sudah melaksanakan secara rutin sebelum memulai pembelajaran BTQ, begitupun sebelum dan sesudah melaksanakan salat fardhu. Materimateri salat yang telah didapatkan, sudah dapat diaplikasikan (praktek) sesuai waktu.

Etika dalam pelaksanaan berwudhu sudahnampakterlihat, misalnya: terstruktur dalam membasuh, budaya antri dan tidak tergesa-gesa dalam berwudhu, bahkan para WBP membersihkan diri (mandi) sebelum melaksanakan salat Jum'at. Tujuan pihak lapas/rutan memberikan pembinaan keagamaan (fiqh), agar warga binaan pemasyarakat dapat mengenal lebih jauh dan bisa diaplikasikan sehari-hari.

Pada prinsipnya, bagaimana warga binaan pemasyarakatan sudah terbiasa melaksanakan ibadah (fardhu dan sunnah) baik secara individu maupun berjamaah. Sedangkan yang menjadi pengelola masjid dan imam rawatib dipercayakan kepada WBP. Sehingga untuk dapat mengetahui tingkat kemampuan dalam penguasaan bacaan salat dan do'a, hanya dapat dilihat pada imam. Karena, yang dipercayakan menjadi imam rawatib, hanya 2 orang saja (Anto dan Haris).

Menurut Asri (pembina), Kaderisasi imam sangat penting dikembangkan, karena ini merupakan program jangka panjang. Sehingga pihak pembina, memprogramkan kaderisasi tertsebut. Ada beberapa kriteria dalam pengkaderisasian imam, diantaranya: melihat kepribadian (sifat dan perilaku keseharian WBP di lingkungan lapas/rutan, penguasaan bacaan/do'a salat (fardhu dan sunnah), dan kepedulian terhadap kemasjidan. Hal tersebut, yang dijadikan sebagai acuan pedoman yang diterapkan pihak lapas/rutan dalam kaderisasi imam.

Pihak lapas/rutan sampai sekarang berupaya mewujudkan kaderisasi imam, agar kegiatan kemasjidan (salat berjamaah) dapat terimplemtasikan setiap hari. Pihak lapas/rutan mengeluarkan aturan/kebijakan dalam pelaksanaan salat berjamaah, yaitu: warga binaan pemasyarakatan tidak semua bisa salat berjamaah di masjid, ini dikarenakan faktor keamanan. Sehingga hanya salat (duhur dan ashar) yang diperbolehkan seluruh WBP melaksanakan secara berjamaah di masjid. Untuk sahalat subuh, magrib dan isya yang 
bisa melaksanakan salat berjamaah bagi WBP yang memiliki kondite baik, diantaranya: Blok koki dan punya kontribusi di lapas/ rutan (membantu tugas-tugas pembina) dengan jumlah yang tidak banyak, yaitu: kurang lebih 21 orang saja.

c) Pengkajian/Siraman Rohani, Pengertian bimbingan secara luas adalah suatu proses pemberian bantuan secara terus menerus dan sistimatis kepada individu dalam memecahkan masalah yang dihadapinya, agar tercapai kemampuan untuk memahami dirinya, mampu untuk mengarahkan dirinya dan mampu menyesuaikan diri dengan lingkungannya, baik dalam keluarga maupun masyarakat. ${ }^{20}$

Kegiatan pengkajian yang dilakukan pihak lapas/rutan hanya pada tataran permukaan (dasar) saja. Misalnya: pengenalan huruf hijaiyah (mengaji) dan hafalan do'a salat, pada prinsipnya bagaimana materi keagamaan bisa memberikan pencerahan bagi WBP yang sifatnya masalah kebaikan. Ada perbedaan pembinaan keagamaan antara pembelajaran BTQ dengan pengkajian, dimana waktu pengkajian terkadang hanya dikondisikan disela-sela pembelajaran BTQ. Sehingga, warga binaan pemasyarakatan minim dalam menyerap pengetahuan dan wawasan keagamaan (pemahaman).

Pencerahan wawasan keagamaan terkadang didapatkan lewat khutbah Jum'at dan peringatan Hari Besar Islam saja, itupun dengan durasi sangat singkat. Pencerahan hal semacam ini merupakan salah satu pilar atau kekuatan guna merubah pola pikir dan

${ }^{20}$ Khoirul Umam dan A. Achyar Aminudin. 1998. Bimbingan dan Penyuluhan. Bandung. CV. Pustaka Setia. h. 12 perilaku warga binaan pemasyarakatan serta merupakan momentum yang tepat bagi pihak pemerintah (Kementerian Agama dan Kemhumkam) dalam mengembangkan kegiatan tersebut.

Pengembangan pembinaan keagamaan yang diimplementasikan pihak Menhunkam (lapas/rutan) selama ini, masih dalam taraf dasar, yaitu: pengenalan huruf hijaiyah dan hafalan do'a salat, sehingga masih memerlukan referensi-referensi yang terkait dengan keagamaan dalam mengoptimalisasikan pembinaan keagamaan khususnya. Karena, warga binaan pemasyarakatan bervariatif dalam hal keilmuan agama yang dimiliki, baik dalam hal usia, kasus, maupun karakter.

Adapun narasumber/uztadz yang biasa memberikan pencerahan/pengkajian keagamaan terkadang kurang maksimal dalam menyampaikan/memberikan materi. Terlepas masalah waktu, pengalaman (jam terbang) dan materi yang disampaikan. Seyogyanya, para narasumber/uztadz memiliki latar belakang yang spesifik pada bidang ilmunya serta materi-materi kegamaan yang disampaikan mudah dicerna, dipahami, serta bisa langsung diaplikasikan oleh warga binaan pemasyarakatan.

Peran penyuluh agama (Kementerian Agama) sangat-sangat dibutuhkan dalam memberikan pencerahaan di lapas/rutan. Ini merupakan momentum bagi Kementerian Agama dalam memberikan kontribusi keagamaan terhadapa masyarakat, khususnya warga binaan pemamasyarakatan di lapas/rutan. Terlepas dari tupoksi Kementerian Agama dalam pelayanan keagamaan terhadap masyarakat, juga bisa memenuhi kebutuhan para penyuluh agama (angka kredit). 


\section{Dampak Prilaku Warga Binaan Pemasyarakatan}

Secara kuantitas jumlah warga binaan pemasyarakatan di lapas Bulukumba dan rutan Bantaeng relatif kecil dibanding dengan warga binaan pemasyarakatan yang ada di lapas/rutan Kabupaten/Kota yang tersebar di Propinsi Sulawesi Selatan. Tetapi, dalam hal pembinaan tidak melihat dari aspek kuantitas (usia dan kasus). Karena, bukan jumlah yang akan dirubah, melainkan bagimana perubahan perilaku, pola pikir dan moral warga binaan pemasyarakatan bisa lebih baik setelah menjalani masa pembinaan di lembaga pemasyarakatan.

Kewajiban para warga binaan pemasyarakatan dalam mengikuti kegiatan pembinaan keagamaan, dimulai saat berstatus WBP tanpa melihat usia, kasus, dan jenis hukuman yang divoniskan. Kebijakan yang dikeluarkan pihak lapas/ rutan, yaitu: 1) Langkah awal para WBP diharuskan bisa mengucapkan dua kalimat syahadat; 2) Mengikuti pembelajaran BTQ; 3) Melaksanakan salat (fardhu dan sunnah) setiap hari; dan 4) Mengikuti kegiatankegiatan pengkajian/siraman rohani; serta 5) Pembinaan lainnya yang terkait dengan pembinaan mental dan akhlak.

Berdasarkan jenis kebijakan yang dikeluarkan pihak lapas/rutan dalam hal pembinaan keagamaan di atas, para warga binaan pemasyarakatan harus bisa mengikuti kegiatan tersebut. Karena minimnya pengetahuan agama yang dimiliki seseorang, sehingga mudah terjerumus ke arah yang negatif. Maka, dengan konsep ini yang dijadikan sebagai pilar, guna memperbaiki perilaku, mental, dan moral para warga binaan pemasyarakatan. Walaupun sifatnya mendasar, tetapi konsep tersebut bisa dijadikan sebagai pedoman dalam pembinaan keagamaan sehari-hari.

Secara garis besar; pihak lapas/rutan yang dijadikan sebagai keharusan bagi warga binaan pemasyarakatan bisa bersyahadat dengan benar, melaksanakan salat, dan membaca Qur'an (mengaji) dengan benar. Untuk mengetehaui perubahan WBP secara keseluruhan setelah mengikuti kegiatan pembinaan keagamaan, hanya dapat dilihat pada aspek salat dan BTQ. Karena, ini merupakan kegiatan rutin yang diikuti oleh semua warga binaan, sehingga nampak terlihat aktivitas ibadah sehari-hari.

Dari hasil evaluasi pihak pembina, belum semua warga binaan pemasyarakatan dapat diberikan kepercayaan dalam memberikan kontribusi di lingkungan lapas/rutan, diantaranya: pengelola kemasjidan (Imam, Muadzin, dan Mengajar BTQ). Dari 300 an WBP, terdapat dua orang (Anto dan Haris) yang dipercayakan mendampingi BIMPAS dalam memberikan pembinaan keagamaan, terkhusus dalam pelaksanaan salat berjamaah (imam). Namun, yang bertidak sebagai muadzin tidak ada penetapan, tergantung dari kesiapan dari salah satu WBP.

Pelaksanaan salat zuhur dan asar secara berjamaah, terkadang kapasitas masjid tidak dapat menampun jamaah, sehingga sebagian melaksanakan di ruang/blok masingmasing. Beda halnya pelaksanaan salat berjamaah pada magrib, isya dan subuh, tidak semua WBP dapat melaksanakan salat berjamaah di masjid. Ini merupakan aturan lapas/rutan dalam hal mengantisipasi kaburnya warga binaan pemasyarakatan.

Antusias warga binaan terlihat saat adzan dikumandangkan, semua 
meninggalkan aktifitasnya dan bergegas menuju ke masjid untuk melaksanakan salat berjamaah tanpa diperintah (diumumkan), begitupun dengan pelaksanaan pembelajaran $\mathrm{BTQ}$, masing-masing warga binaan membawa Iqra, Qur'an. Sebelum melaksanakan pembelajaran BTQ, sebahagian besar WBP melaksanakan salat sunnah (du'ha). Pembiasan-pembiasan yang dilakukan oleh warga binaan dalam melaksanakan ibadah, tidak terlepas dari ketauladanan para pembina. Begitupun halnya, bagi WBP yang dipercayakan para ruang-ruang lain dalam memberikan kontribusi kepada pihak lapas/rutan dalam hal pelayanan dan administrasi.

Tidak semua warga binaan pemasyarakatan diberikan kesempatan untuk diperbantukan dalam melayani warga binaan pemasyarakatan dan BIMPAS setiap hari, misalnya: koki, adminstrasi, kemasjidan, kebersihan di luar dan dalam lapas/rutan. Menurut Kepala Seksi Bimpas (Abd. Rahman, S.Sos), keterlibatan WBP dalam berkontribusi dilingkungan lapas/ rutan, harus memiliki memenuhi kriteria, diantaranya: rajin beribadah, santun dalam berkomunikasi, dan taat dalam aturan.

Ada beberapa contoh perubahan terhadap warga binaan pemasyarakatan selama mengikuti kegiatan pembinaan, terutama dalam hal ibadah, diantaranya: Dandu (WBP) berusia 16 tahun dengan kasus pembunuhan, setelah menjalani masa pembinaan sudah rutin melaksanakan salat fardhu, sebelumnya tidak pernah malaksanakan salat. Begitupun halnya dengan WBP (Anto, Haris, H. Saharuddin) sejak keberadaan mereka, pihak Bimpas dan Pelayanan lapas/rutan sangat terbantu, terutama dalam mengoprasionalisasikan kegiatan keagamaan.

\section{Pendukung dan Penghambat Pembinaan}

Eksistensi kegiatan keagamaan dapat berjalan secara efektif dan efesiensi, apabila ditunjang dengan saranan dan prasarana. Kepemilikan sarana dan prasarana di lembaga pemasyarakatan dan rumah tahanan terlihat ada perbedaan, diantaranya: ruang belajar, fasilitas, dan kuantitas (pengelola), serta yang tak kalah pentingnya adalah sumber daya manusia (SDM) pembina keagamaan.

Peran organisasi keagamaan (wahdah) dan Lembaga Pemasyarakatan dan Rumah Tahanan memiliki kepedulian yang tinggi dalam memberikan bimbingan serta didukung oleh warga binaan pemasyarakatan dalam mengikuti kegiatan tersebut. Begitupun dengan Kementerian Agama (penyuluh agama) pernah memberikan pembinaan sampai 2008 - 2009. Sehingga, kegiatan pembinaan keagamaan masih diimplementasikan sampai sekarang.

Ruang pembelajaran telah disiapkan oleh pihak lapas/rutan, walaupun dengan kapasitas yang terbatas, tetapi tidak mengurangi nilai kegiatan dan semangat pembina dalam memberikan bimbingan. Terutama pada kegiatan BTQ, dimana para warga binaan telah mempersiapkan atau memiliki Iqra dan Qur'an, sehingga memudahkan dalam melangsungkan kegiatan pembelajaran. Disamping, para WBP memiliki inisiatif dalam pengadaan Qur'an (nyumbang) atas dasar kemauan sendiri, tanpa ada tekanan dari pihak Bimpas. 
Menurut H. Saharuddin (WBP) rutan Bantaeng, kegiatan pembinaan keagamaan dapat eksis atau berkesinambungan apabila metode yang digunakan adalah metode asistensi. Metode tersebut dapat menghasilkan kaderisasi dan memudahkan bagi pihak (pembina) dalammengaplikasikan secara rutin kegiatan bimbingan. Misalnya: mengevaluasi kompetensi WBP, baik dari aspek keilmuan yang dimiliki maupun dari aspek perilaku (kepribadian) yang dimilki bagi warga binaan. Tak kalah pentingnya adalah para pembina memaksimalkan diri dalam memperlihatkan ketauladananya dalamberkomunikasi(interaksi), berperilaku sehari-hari saat memberikan bimbingan baik didalam maupun di luar ruang kegiatan. Hal ini dilakukan dengan alasan, karena WBP bukan orang jahat, tetapi orang yang masih kabur dalam memahami ilmu agama. Sehingga, diperlukan pembiasanpembiasaan yang sifatnya baik, agar kelak mereka dapat mengaktualisasikan setelah menyelesaikan masa pembinaannya.

Pelaksanaan pembinaan keagamaan berjalan secara alami, karena adanya keterbatasan yang dimiliki pihak lapas/ rutan, diantaranya: a) Kapasitas ruang kegiatan; b) Reverensi (buku-buku agama, Iqra, dan Qur'an); c) Tenaga (pengelola) memiliki ilmu yang tidak linear dengan tupoksinya; dan d) Minimnya SDM. Pemenuhan ruang dan fasilitas kegiatan pembinaan belum terkategori layak, karena kegiatan pembinaan masih dilaksanakan secara integrasi dalam satu ruang. Sehingga, optimalisasi kegiatan belum dapat berjalan secara maksimal. Efektifitas dan efesiensinya suatu kegiatan pembinaan, selayaknya para warga binaan pemasyarakatan dikelompokkan berdasarkan usia dan kasus.
Sumber referensi masih didominasi dari buku-buku ilmu pengetahuan umum (keterampilan). Sedangkan untuk bukubuku agama terbilang belum ada, begitupun halnya dengan Iqra dan Qur'an terkadang pengadaannya dari inisiatif warga binaan pemasyarakatan sendiri.

Para pengelola (Bimpas dan Pelayanan), masih bertumpuh pada Organisasi Keagamaan, Pembina lapas/ rutan, dan warga binaan pemasyarakatan yang memiliki keilmuan (kompetensi) keagamaan. Itupun, tidak semua memiliki ilmu pengetahuan yang didapatkan secara akademik. Pada prinsipnya, bagaimana warga binaan pemasyarakatan bisa mendapatkan pencerahan dan pemahaman keagamaan dalam bentuk baca tulis Qur'an, salat berjamaah, serta dapat merubah pola pikir dan tingkah laku dengan baik.

Pengembangan pembinaan keagamaan belum dikelola secara profesional, karena terjadi kefakuman antara pihak lapas/rutan dengan Kementerian Agama (penyuluh agama) dalam mensinergikan pembinaan keagamaan, baik dalam pemenuhan fasilitas maupun penempatan tenaga (pengelola) yang belum relevan dengan profesi sebagai pembina keagamaan.

\section{PENUTUP}

Pelaksanaan pembinaan keagamaan diaktualisasikan secara integrasi, dengan metode asistensi (pengkaderan). Karena, minimnya tenaga pengelola yang memiliki SDM dan latar belakang pendidikan pengelola (pembina) tidak linear dengan tupoksi. Sehingga pembinaan keagamaan belum berjalan secara optimal. Penggunaan metode pembinaan masih dalam bentuk 
manual (alami) dan terbatasnya media pembelajaran yang dijadikan sebagai rujukan/pedoman, dalam melangsungkan kegiatan pembinaan, diantaranya: buku bacaan agama, Iqra, dan Qur'an. Secara signifikan dampak pembinaan kegamaan terhadap warga binaan pemasyarakatan dapat dilihat pada tataran implementasi baca tulis qur'an (BTQ) dan melaksanakan salat secara berjamaah (fiqh). Karena, ini merupakan ketetapan pihak lapas/ rutan dalam mengaktualisasikan kegiatan pembinaan keagamaan (Bimas dan Pelayanan).

Beberaparekomendasiyaitu:diharapkan pemerintah terkait (Kementerian Agama, Kemenhumkam, Pemda) agar bisa lebih meningkatkan sinergisitas dalam membangun komunikasi serta selektif dalam merekrut dan menempatkan tenaga penyuluh berdasar pada latar belakang pendidikan. Pemenuhan fasilitas pembinaan keagamaan (media) pembelajaran sangat penting, dalam mewujudkan eksistensinya kegiatan pembinaan. Sehingga, diperlukan adanya kerjasama antara pihak Menhumkan dengan lembaga/instansi terkait dalam pengadaan yang berdasar pada kebutuhan warga binaan pemasyarakatan.

Pengembangan pembinaan keagamaan diperlukan adanya inovasi dan kreatifitas pihak pembina. Sehingga pemahaman, pengetahuan, dan wawasan keagamaan warga binaan pemasyarakatan tidak hanya terfokus pada dua aspek saja.

\section{UCAPAN TERIMA KASIH}

Penulis menghaturkan banyak terima kasih kepada Balai Litbang Agama Makassar yang ikut berkontribusi pada penelitian ini, terutama pada kalangan responden/ informan (Kementrian Agama Kabupaten Bulukumba dan Bantaeng, serta LAPAS dan RUTAN). Semoga laporan penelitian ini, bisa dijadikan sebagai sumber data dan informasi, terkhusus pada pemangku kebijakan Kementerian Agama RI.

\section{DAFTAR PUSTAKA}

A. Nasir, Sahilun (1999): Ilmu Dakwah. Jember, STAIN Press.

Alwi, Hasan (2002): Kamus Bahasa Indonesia. Jakarta, Balai Pustaka.

(2007): Kamus Besar Bahasa Indonesia. Jakarta, Balai Pustaka

Anwar (2007): Bimbingan dan Konseling Islam (Teori dan Praktek), Semarang, Cipta Prima Nusantara.

Dipraja, R. Achmad S. Soema dan Romli Atmasasmita (1979): Sistem Pemasyarakatan Di Indonesia. Bandung, Percetakan Ekonomi.

Faqih, Ainurrahim (2000): Dasar-Dasar Bimbingan Dan Konseling Islami. Yogyakarta, UII Press

Gunakaya, A.Widiada (1988): Sejarah Dan Konsepsi Pemasyarakatan. Bandung, Armico.

Hellen (2002): Bimbingan dan Konseling, Jakarta, Ciputat Press.

Jalaluddin (1996): Psikologi Agama. Pengaruh Pendidikan Terhadap Jiwa Keagamaan. Jakarta, PT. Raja Grafindo Persada

Kafie, Jamaluddin (1993): Psikologi Dakwah. Surabaya, Indah Press

Khoirul Umam dan A. Achyar Aminudin (1998): Bimbingan Dan Penyuluhan. Bandung, CV. Pustaka Setia. 
Moleong, Lexy J (2011): Metodologi Penelitian Kualitatif. Bandung, PT. Rosdakarya

Muidin, Gultom (2008): Perbandingan Hukum Terhadap Anak Dalam Sistim Peradilan Pidana Anak di Indonesia, Jakarta, Refika Aditama.

Panjaitan, Petrus Irwan dan Simonangkis, Pandapotan (1995): Lembaga Pemasyarakatan Dalam Perspektif Sistem Peradilan Pidana. Jakarta, Pustaka Sinar Harapan.

, Pasal 1 Undang-Undang Republik Indonesia Nomor 12 Tahun 1995 Tentang Pemasyarakatan, Redaksi Sinar Grafika

Peraturan Pemerintah Republik Indonesia Nomor 32 Tahun 1999 tentang Syarat dan Tata Cara Pelaksanaan Hak Warga Binaan Pemasyarakatan

Poernomo, Bambang (1986): Pelaksanaan Pidana Penjara dengan Sistem Pemasyarakatan.Yogyakarta, Liberty.
Print, Darwan (2003): Hukum Anak Indonesia. Bandung, PT. Citra Aditya Bakti.

Priyatno, Dwidja (2006): Pidana Penjara di Indonesia. Bandung, Refika Aditama.

Sri, Sutatiek (2013): Rekontruksi Sistem Sanksi Dalam Hukum Pidana Anak Indonesia. Yoyakarta, Aswojo Pressindo.

Undang-undang Nomor 11 Tahun 2012, tentang Sistem Peradilan Anak

Undang-undang Nomor 23 Tahun 2012, tentang Perlindungan Anak Dalam Rangka Meningkatkan Efektifitas Penyelenggaraan Perlindungan Anak

Wagiati Soetedjo dan Melani (2013): Hukum Pidana Anak. Bandung, Refika Aditama).

Waluyo, Bambang (2000): Pidana dan Pemidanaan. Jakarta, Sinar Grafika. 